\title{
Granting Inmates Information Technology-Based Rights
}

\author{
Nevey Varida Ariani ${ }^{1}$ \\ ${ }^{1}$ The Agency of Research and Development of Law and Human Rights \\ *Corresponding author. Email: nevey.ariani@yahoo.com
}

\begin{abstract}
The world has entered industrial revolution 4.0, which has an effect on granting inmates rights that are based on information technology (IT) and encourages active participation of communities in supporting the implementation of an appropriate correctional system. However, this use of IT has not been optimized to ensure that, together with their families, inmates are able to obtain relevant information and that there is certainty in obtaining their rights. Therefore, this study aimed to investigate the use of IT in granting inmates their rights. Thus, the study employed an evaluative juridical approach with mixed methods (quantitative and qualitative). Data were collected through interviews, observations, and surveys using a SERVQUAL (service quality) model with the following five dimensions: tangibility, reliability, accessibility, communication, and credibility. The findings show that service quality is influenced by the credibility and integrity of the correctional staff. Therefore, the readiness of facilities and infrastructure, such as to add some features in the correctional database system, encourage self-service, and to ensure credibility in collecting inmates' data, can help curb the shortcomings associated with employees' credibility and integrity in the process of granting inmates their IT-based rights.
\end{abstract}

Keywords: Accessibility, Rights of Inmates, Information Technology

\section{INTRODUCTION}

There are varied definitions of industrial revolution 4.0 because this is a developing term. Angela Merkel (2014) defines industry 4.0 as a comprehensive transformation in all aspects of production, which combines digital technology and the internet with the conventional industry. The effect of implementing this technology is increasing production efficiency and increasing productivity and competitiveness in accordance with the needs of the industry based on digital technology as well as industrial revolution 4.0. This definition also covers the performance of human employees. For example, it is now possible to track the movements of every employee while in the office. From the movement, one can establish, for example, that the employees spend too much time in one department and, as a result, the department needs renovation. The same applies to the development of technology related to access to information technology (IT)-based inmate rights in Indonesia.

Granting prisoners these rights prepares them for their return to society. One method of achieving this is by granting remission to prisoners. This is an interesting topic because remission is, at present, no longer a gift but part of the rights of prisoners who fulfill stipulated conditions (Efendi 2018, p. 194).

To implement those rights, the law is not only focused on legal certainty but also on the aspects of justice and its benefits. It aims at protecting the general population, creating an orderly society, realizing justice in the community, and ensuring certainty in carrying out all the rights and obligations of the community to create a prosperous society (Butarbutar 2016, p. 8).

Based on the Correctional Bureaucratic Reform Process Roadmap for 2020-2024 Improvement of Correctional Performance to Realize Information Technology-Based Social Reintegration, the Regulation of the Minister of Law and Human Rights Number 3 of 2018 concerning Terms and Procedures for Giving Remission, Assimilation, Family Visit Leave, Conditional Exemption, Free Approach Leave, and Conditional Leave were set, and they aim to encourage active participation of communities in supporting the implementation of an appropriate correctional system. 
This roadmap is in tandem with the achieved social reintegration based on IT in correctional institutions.

Extramural granting of inmates' rights is an effort carried out by the correctional system to prepare inmates for a healthy reintegration into the community. This allows them to play a role as members of a free and responsible community. In granting these rights, inmates must fulfill the requirements of substantively and administratively following the prescribed mechanism. In line with the bureaucratic reform and e-government program, the process of granting inmates' rights in the form of remission, assimilation, leaves to visit their families, and parole is facilitated by the use of IT. The actualization of the use of IT in the correctional field has been achieved through the use of a Correctional Database System called SDP. SDP is an Indonesian abbreviation that stands for Sistem Database Pemasyarakatan. It is a mechanism for reporting and consolidating the management of inmates' data, which functions as a work aid according to the needs of the Correctional Technical Implementation Unit, the Correctional Division, and the Directorate General of Correctional.

The Correctional Database System contains features related to correctional services, including registration management features that accommodate the data record of inmates and inmate registration data from the entry to the exit levels, which contain integration features that accommodate the implementation of parole proposals, conditional leaves, free approaching leaves, security features that accommodate security management (such as placement prisoner blocks with maximum or minimum security), and maintenance features that accommodate health care management for the prisoners.

According to previous research conducted in the Tangerang Correctional Institution for Women, paying fines and replacement money in accordance with court decisions is one of the factors inhibiting remission (Yanto, Rachmayanthy, \& Satriana 2019). Therefore, the aim of using IT in the process of granting inmates their rights is to facilitate expeditious delivery of services, efficiency, accountability, accuracy, and supervision within the correctional system. This helps inmates to easily access the information they need and follow the process easily because they are certain about the process, its efficiency, and transparency. However, based on research conducted by expert staff in 2018, the use of IT in the granting inmates their rights has not been optimized to ensure that together with their families, they are able to obtain relevant information and there is certainty in obtaining the rights provided for (Expert Staff 2018). Therefore, it is necessary to conduct research related to accessibility of prisoners' rights (information technology-based remission, assimilation, leaves to visit their families (CMK), conditional release
(PB), free approaching s (CMB), and conditional leaves (CB)).

This research was carried out using an evaluative juridical approach with mixed methods (quantitative and qualitative). Data were collected through interviews, observations, and surveys using the SERVQUAL (service quality) model with the following five dimensions (Ramseook-Munhurrun, Lukea-Bhiwajee, \& Naidoo 2010):

- Tangibility (access to facilities and infrastructure);

- Reliability (the ability of officers to perform services reliably and accurately);

- Accessibility (data accuracy and effectiveness in using the application);

- Communication (users are informed in the language that suits their needs, proximity to the officer, and complaint service); and

- Credibility (truth, honesty, and supervision).

Table 1. Research Instrument*

\begin{tabular}{|c|c|c|}
\hline No & DIMENSION & INDICATOR \\
\hline 1 & Tangibility & $\begin{array}{l}\text { a. Facilities and infrastructures } \\
\text { b. Procedure or plot } \\
\text { c. Implementation procedure }\end{array}$ \\
\hline 2 & Reliability & $\begin{array}{l}\text { a. Officers' competence about } \\
\text { SDP } \\
\text { b. Officers' professionalism } \\
\text { c. Authority and officers' } \\
\text { treatment } \\
\text { d. Coordination between the } \\
\text { officers and law enforcement } \\
\text { official }\end{array}$ \\
\hline 3 & Accessibility & $\begin{array}{l}\text { a. Services in the SDP } \\
\text { application } \\
\text { b. Accuracy in SDP applications } \\
\text { c. Format in the SDP application } \\
\text { d. The ease of using SDP } \\
\text { applications } \\
\text { e. Certainty time of SDP } \\
\text { application }\end{array}$ \\
\hline 4 & $\begin{array}{l}\text { Communicatio } \\
\mathrm{n}\end{array}$ & $\begin{array}{l}\text { a. Inmates rights to service } \\
\text { b. Complaint service } \\
\text { c. Information provision services }\end{array}$ \\
\hline
\end{tabular}




\begin{tabular}{|l|l|l|}
\hline 5 & Credibility & $\begin{array}{l}\text { a. The clerk that asks for } \\
\text { compensation } \\
\text { b. Tamping that asks for } \\
\text { compensation } \\
\end{array}$ \\
& $\begin{array}{l}\text { c. Application monitoring by } \\
\text { officers } \\
\text { d. Application benefits are real }\end{array}$ \\
\hline
\end{tabular}

a. Based on the results of the research on the accessibility of IT by inmates conducted by The Agency of Research and Development of Law and Human Rights in 2019

Based on the five dimensions, the analysis was performed using a Likert scale of $1-11$. The value of 1 showed a considerably bad value while the value of 11 showed a considerably good value. Random sampling was used to select the research respondents. In total, 500 (five hundred) respondents spread across several Correctional Systems-DKI Jakarta Province (Cipinang Correctional Institution, Jakarta Correctional Institution for Drug Addicts, Jakarta Correctional Institution for Women, Salemba, and Juvenile Detention Center Salemba Correctional Institution); East Java Province (Surabaya Correctional Institution, Malang Correctional Institution, Malang Correctional Institution for Women, Lamongan Correctional Institution, and Pasuruan Correctional Institution); West Java Province (Cirebon Correctional Institution, Sukamiskin Correctional Institution, Banceuy Correctional Institution, Cibinong Correctional Institution, Women Correctional Institution Correctional Institution of Bandung, and Bandung Correctional Institution for Drug Addicts); and the Province of North Sumatra (Medan Correctional Institution, Medan Juvenile Detention Center, Medan Correctional Institution Correctional Institution for Women, Pematang Siantar Correctional Institution, and Pematang Siantar Correctional Institution for Drug Addicts)—was selected.

The results of the present study will contribute to the existing literature, which is instrumental in the development of law in Indonesia and can be used as a basis for consideration in policy formulation on IT-based inmate rights, particularly in the Ministry of Law and Human Rights. In addition, the results will contribute toward establishing the legal basis for granting some rights to prisoners, such as remission, assimilation, family leaves (CMK), parole (PB), leave before free (CMB), and conditional leaves (CB), based on IT.

\section{RESULTS}

Several factors were analyzed in every location as part of the general description. These factors included the level of education, occupation, age, and type of service.

\subsection{Level of Education}

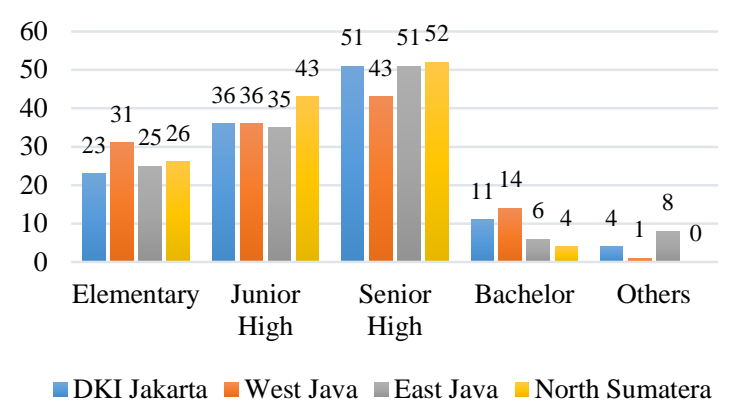

Figure 1 The Latest Education of Prisoners (Source: The Agency of Research and Development of Law and Human Rights, 2019)

In DKI Jakarta Province, of the 125 respondents who participated in this research, $18 \%$ were elementary school graduates, 29\% were junior high school graduates, $41 \%$ were senior high school graduates, $9 \%$ were bachelor degree holders, and the remaining $3 \%$ received "other" education.

In West Java, of the 125 respondents who participated in this research, $25 \%$ were elementary school graduates, $29 \%$ were junior high school graduates, $34 \%$ were senior high school graduates, $11 \%$ were university graduates, and the remaining $1 \%$ received "other" education.

In East Java, of the 125 respondents who participated in this research, $20 \%$ were elementary school graduates, $28 \%$ were junior high school graduates, $41 \%$ were high school graduates, $5 \%$ were tertiary education graduates, and the remaining $6 \%$ received "other" education.

In North Sumatera, of the 125 respondents who participated in this research, $21 \%$ were elementary school graduates, $34 \%$ were junior high school graduates, $42 \%$ were senior high school graduates, and the remaining $3 \%$ were bachelor degree holders.

Generally, the statistics on the latest education for most prisoners were as follows: senior high school with a total number of 197 prisoners (39\%), followed by junior high school (30\%), elementary school (21\%), and bachelor degree holders (7\%). There were only 13 prisoners (less than 3\%) who had received other education. 


\subsection{Occupation}

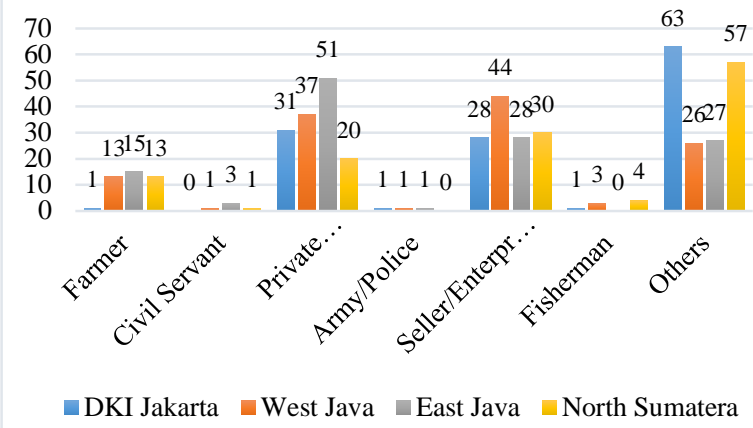

Figure 2 The Occupation of Prisoners (Source: The Agency of Research and Development of Law and Human Rights, 2019)

In terms of work, of the 125 respondents in DKI Jakarta, $1 \%$ were farmers, $1 \%$ were members of either the army or police, $1 \%$ were fishermen, $22 \%$ were sellers or entrepreneurs, $25 \%$ were private employees, and $50 \%$ were engaged in other types of work

In West Java, of the 125 respondents who participated in this study, $10 \%$ were farmers, $1 \%$ were civil servants, $30 \%$ were private employees, $1 \%$ among were members of the either the army or police, $35 \%$ were sellers or entrepreneurs, $2 \%$ were fisherman, and $21 \%$ were engaged in other types of work.

In East Java, of the 125 respondents who participated in this study, $22 \%$ were traders or entrepreneurs, $12 \%$ were farmers, $2 \%$ were civil servants, $1 \%$ comprised members of the TNI/Polri, $41 \%$ were private employees, and the remaining $22 \%$ were engaged in other types of work.

In North Sumatera, of the 125 respondents who participated in this study, $10 \%$ were farmers, $1 \%$ comprised civil servants, $16 \%$ were private employees, $24 \%$ were sellers or entrepreneurs, $3 \%$ were fishermen, and $46 \%$ were engaged in other types of work.

Generally, from the statistics on the occupation of the prisoners, most prisoners were engaged in other types of work (173 prisoners or $35 \%)$, followed by private employees $(28 \%)$, sellers $(26 \%)$, and farmers $(8 \%)$. Only a few prisoners worked as fisherman, civil servants, and army/police, with their total number being 16 (3\% of the participants).

\subsection{Age}

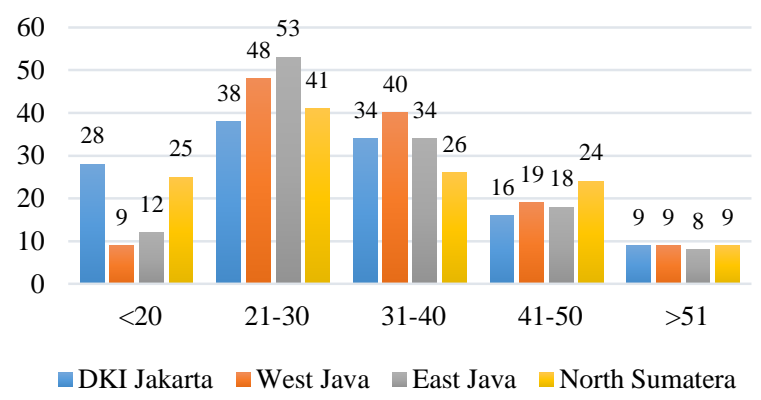

Figure 3 The Age of Prisoners (Source: The Agency of Research and Development of Law and Human Rights, 2019)

Based on the research conducted in DKI Jakarta, the respondents aged 12-16 years old were 5\%, those aged 17-21 were $18 \%$, those aged $22-26$ were $18 \%$, those aged $27-31$ were $13 \%$, those aged $32-36$ were $13 \%$, those aged $37-41$ were $14 \%$, those aged $42-46$ were $6 \%$, those aged $47-51$ were $6 \%$, those aged 52-56 were $4 \%$, those aged 57-61 were $1 \%$, and those aged above 62 years were $2 \%$.

In West Java, the respondents aged 17-21 years old were $7 \%$, those aged 22 years to 26 years were $18 \%$, those aged $27-31$ were $21 \%$, those aged $32-36$ were $18 \%$, those aged $37-41$ were $14 \%$, those aged $42-46$ were $7 \%$, those aged $47-51$ were $8 \%$, those aged $52-56$ were $5 \%$, and those aged above 62 years were $2 \%$.

In East Java, the respondents aged 17-21 years old were $10 \%$, those aged $22-26$ were $30 \%$, those aged $27-$ 31 were $13 \%$, those aged $32-36$ were $19 \%$, those aged $37-41$ were $8 \%$, those aged $42-46$ were $7 \%$, those aged $47-51$ were $7 \%$, those aged $52-56$ were $4 \%$, and those aged above 62 years were $2 \%$.

In North Sumatera, the respondents who were less than 20 years old were $20 \%$, those aged 21-30 were $33 \%$, those aged $31-40$ were $21 \%$, those aged $41-50$ were $19 \%$, and those above 51 years were $7 \%$.

Generally, the age of most prisoners was between 21-30 years old (with a total number of 180 prisoners or $36 \%$ ), followed by those aged $31-40$ years old (27\%), $41-50$ years old $(15 \%)$, and under 20 years old $(15 \%)$. There were only 35 prisoners $(7 \%)$ aged above 51 years old. 


\subsection{Type of Service}

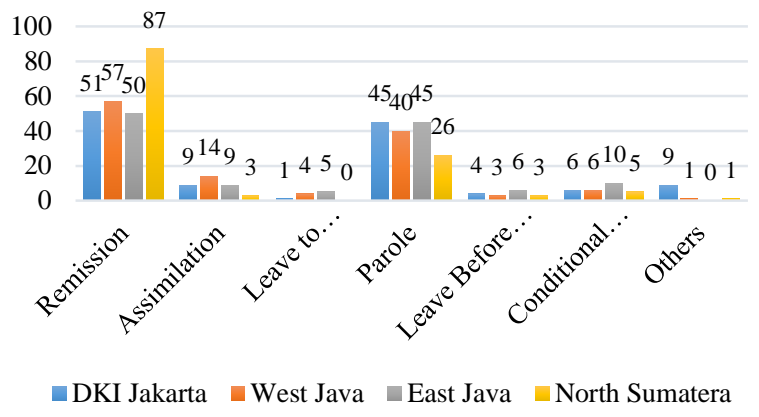

Figure 4 Type of Service Received By Prisoners (Source: The Agency of Research and Development of Law and Human Rights, 2019)

Out of the 125 respondents in DKI Jakarta, majority of the respondents had received services in the form of remission $(41 \%)$, followed by giving parole $(36 \%)$, giving assimilation (7\%), giving other services (7\%), giving conditional leave (5\%), giving leave before free $(3 \%)$, and giving leave to visit family (1\%).

Out of the 125 respondents in West Java Province, majority of the respondents had received services in the form of remission $(46 \%)$, followed by giving parole $(32 \%)$, giving assimilation (11\%), giving conditional leave $(5 \%)$, giving leave to visit family (3\%), giving leave before free $(2 \%)$, and giving other services $(1 \%)$.

Out of the 125 respondents in East Java, majority of the respondents had received services in the form of remission $(40 \%)$, followed by giving parole $(36 \%)$, giving conditional leave (8\%), giving assimilation (7\%), giving leave before free (5\%), and giving leave to visit family (4\%).

Out of the 125 respondents in North Sumatra Province, majority of the respondents had received services in the form of remission $(70 \%)$, followed by giving parole $(21 \%)$, conditional leave $(4 \%)$, assimilation (2\%), giving leave before free $(2 \%)$, and giving other services (1\%).

Overall, 49\% (245 prisoners) of the prisoners had received remission and $31 \%$ (156 prisoners) of the prisoners had received parole. The remaining 20\% (99 prisoners) received assimilation, leave to visit family, leave before free, conditional leaves, and other services.

\section{RESEARCH RESULTS}

This study presents the results based on five dimensions. Each of these dimensions consists of an indicator that is mentioned in the instruments of this research (see Table 1).

\subsection{Tangibility}

The tangibility dimension covers the access of the correctional institutions to relevant facilities and infrastructure. It is based on three indicators, which are facilities and infrastructure, procedure or plot, and implementation procedure. They are recapitulated in the diagram below.

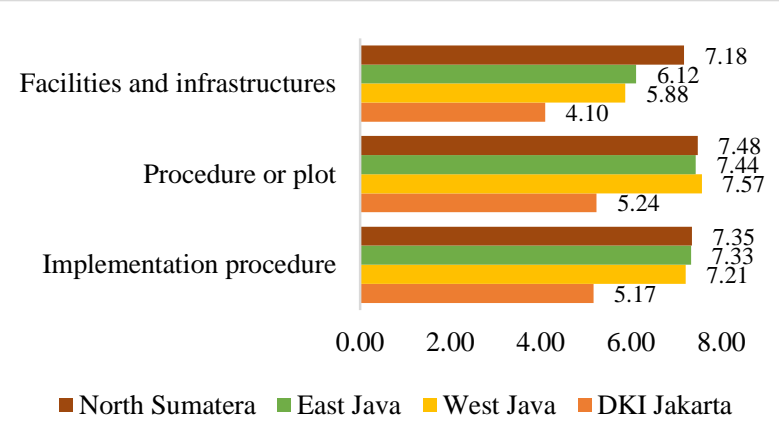

Figure 5 The Tangibility Dimension (Source: The Agency of Research and Development of Law and Human Rights, 2019)

From the graph above, it can be seen that the tangibility dimension in North Sumatera is much better compared to the results of other provinces. The correctional institution there provides the best facilities and infrastructure. It also has the best implementation procedure compared to the other three locations. In both indicators (i.e., facilities and infrastructure and implementation procedure), it is followed by East Java, West Java, and DKI Jakarta. When it comes to the procedure or plot indicator, North Sumatera is the second best after West Java. It is then followed by East Java and DKI Jakarta.

It is worth noting that when it comes to the implementation procedure, inmates in both East and West Java cannot easily access information about their rights through a self-service application because there is only one unit available and most of the time it's not functioning. In DKI Jakarta, it is also worth mentioning that it is difficult for inmates to access information about their rights because there is only one unit available, which is also not functioning most of the time.

Overall, the average value of the tangibility dimension in North Sumatera is 7.34, followed by East Java at 6.97, West Java at 6.88, and DKI Jakarta at 4.84.

\subsection{Reliability}

The reliability dimension includes evaluating the ability of the officers to perform services reliably and accurately. It has four indicators, which include: the competency of the officers (in relation to using the SDP system), the professionalism of the officers in carrying out their duties, the manner in which the authority and 
the officers treat inmates, and the coordination between the officers and other law enforcement officers.

$$
\begin{aligned}
& \text { Officers competence about } \\
& \text { SDP }
\end{aligned}
$$
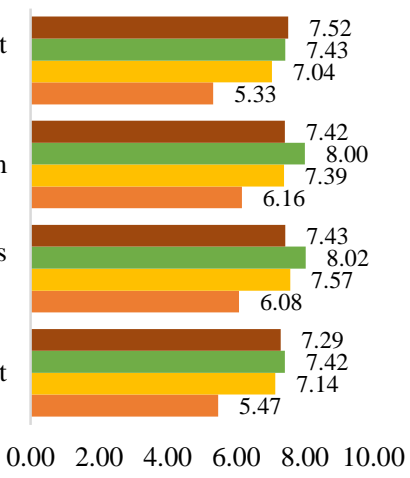

Figure 6 The Reliability Dimension (Source: The Agency of Research and Development of Law and Human Rights, 2019)

From the graph above, it is clear that East Java attained the best score in the three indicators; that is, the aspect of officers' professionalism, how the authority and officers treat inmates, and coordination between the officers and other law enforcement officers. On the other hand, North Sumatera ranked as the best when it came to the competence of the officers in using the SDP system. DKI Jakarta ranked as the worst in all the four indicators. The average score of the reliability dimension attained by each of the provinces was as follows: 7.72 for East Java, 7.44 for North Sumatera, 7.29 for West Java, and 5.76 for DKI Jakarta.

It is worth noting that, especially in DKI Jakarta, the officers specifically had competencies related to duties and functions in providing services based on IT rights. However, the coordination required to facilitate the fulfillment of the necessary conditions for remission rights to be granted was perceived as an obstacle by the officers. The inmates experienced difficulties in receiving letters. They, therefore, often asked for help from the officers but the officers also found it difficult to request the letters, and there were indications that other law enforcement officers requested a fee.

\subsection{Accessibility}

The accessibility dimension was based on five indicators, which are services, accuracy, format of the SDP applications, the ease of use of the SDP system, and the certainty of the SDP system application time.

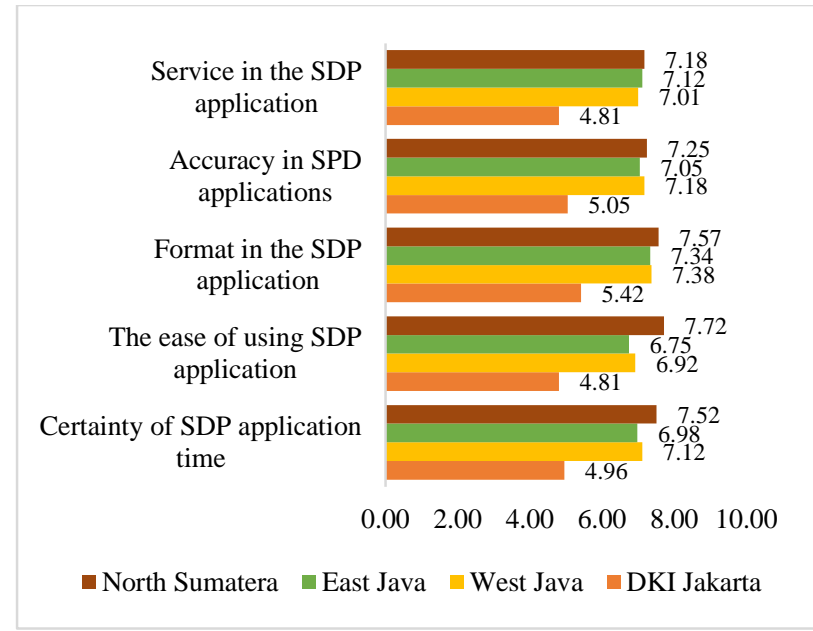

Figure 7 The Accessibility Dimension (Source: The Agency of Research and Development of Law and Human Rights, 2019)

From the above graph, it is clear that North Sumatera has the best accessibility dimension in all the five indicators (with an average score of 7.44), while DKI Jakarta has the worst (with an average score of 5.01). The average scores of the other two provinces are 7.12 for West Java and 7.05 for East Java.

It is important to note that in DKI Jakarta, the accuracy of the time taken by the officers to input files related to the justice collaborator letters for specific criminal acts was an obstacle. The delay was further compounded by the community research process, which was also slow. In West Java, the implementation process also faced major challenges occasioned by of the time taken by the officers to grant IT-based rights that are not within the realm of the provided rights. The delay was further amplified by the community research process, which was quite slow. In East Java, the implementation process is still facing major obstacles in regards to the ability of the officers to grant IT-based rights in a timely manner (time accuracy). This challenge is occasioned by difficulties in data consolidation. Delays also occur when managing document requirements (i.e., justice collaborator letters) on special criminal acts.

\subsection{Communication}

The communication dimension consists of prisoners' rights services, complaint services, and provision of information services. It covers the areas of being informed using the appropriate language, proximity to the officers, and complaint services. 


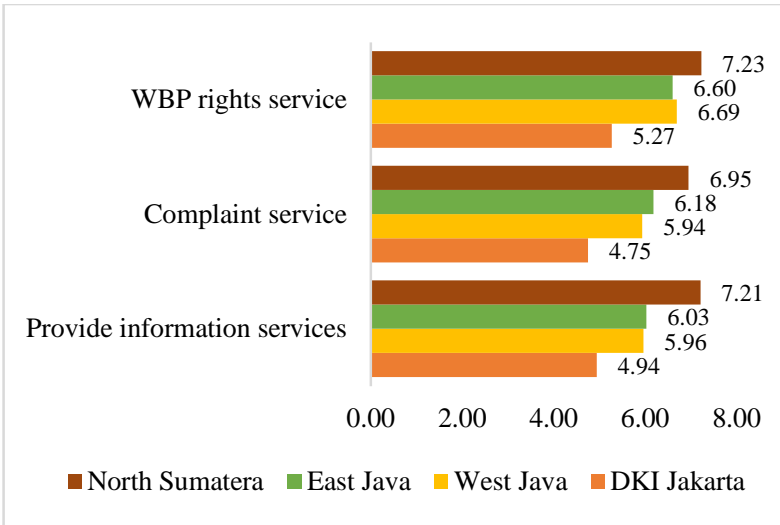

Figure 8 The Communication Dimension (Source: The Agency of Research and Development of Law and Human Rights, 2019)

From the graph above, it is clear that North Sumatera has the best communication dimension in all the three indicators (with an average score of 7.13), while DKI Jakarta has the worst (with an average score of 5.98). The average score from the other two provinces are 6.20 in West Java and 6.27 in East Java.

The researchers also observed that the inmates are not well informed about the terms and procedures for granting rights. Although banners were available, in most instances, the inmates were not informed about their rights.

\subsection{Credibility}

Credibility is the last dimension. It simply consists of truth, honesty, and supervision, which are further broken down into four indicators: application benefits are real, application monitoring by officers, tamping that asks for compensation, and clerks that ask for compensation.

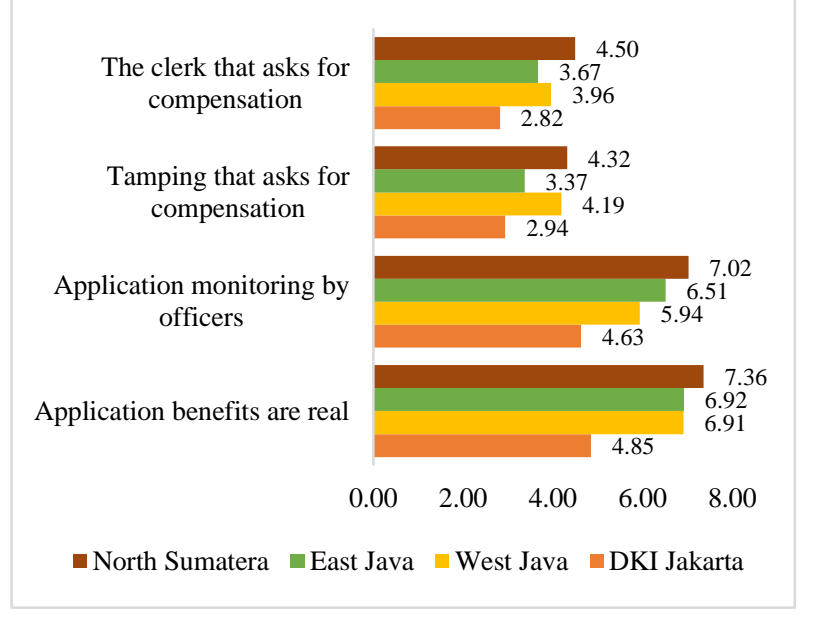

Figure 9 The Communication Dimension (Source: The Agency of Research and Development of Law and Human Rights, 2019)

From the graph, North Sumatera has the best credibility dimension in all the four indicators (with an average score of 5.80), while DKI Jakarta has the worst (with an average score of 3.81). The average scores for the other two provinces are 5.25 in West Java and 5.12 in East Java.

In this dimension, the main focus lies in the process of granting rights where officers demand some sort of compensation. The participants' statements suggest that some officers request for money or goods in order to provide IT-based rights services to inmates. The purpose of these requests is to speed up the process, but the actual implementation still takes a long time.

\section{ANALYSIS}

The results of "The Accessibility of the Rights of Assisted Citizens Based on Information Technology" research indicate that in each correctional institution, high school students within the age bracket of 21-30 years are very productive. However, this research does not specify their work to show the relationship between the knowledge level of the inmates to the ability to access their rights and use IT. This is due to the following:

- From the tangibility dimension (related to the use of facilities and infrastructure), the self-service machines in the correctional institutions, even though available, they are not always operational. In addition, the availability of computers in the information center room or in the registration room is still limited, thus directly affecting the provision of information technology-based rights services to inmates.

- From the reliability dimension (the ability of officers to perform services reliably and accurately), officers have the relevant competencies and capabilities and perform their duties according to the SOP or the path set in providing information technology-based rights services to inmates. However, the implementation of this process is still stifled by lack of coordination between the registration section and the development and education section due to lack of congruence in data integration. Another obstacle is specifically related to the coordination with the other law enforcement officials in instances where inmates experience difficulties obtaining a justice collaborator letter relating to specific criminal acts, which specify this as a condition for granting inmates rights.

- From the Accessibility dimension (data accuracy and effectiveness in using the application), the accuracy of data or information relating to inmates' can be accurate but its effectiveness in relation to the inmates' rights might still not appropriate because of the process delays occasioned by system and server interruptions at the center as well as the consolidation process involving the Directorate General of Correctional, which takes a long time. 
- From the communication dimension, it can be seen that direct contact still occurs with officers who provide information technology-based rights to inmates, despite the fact that the information technology-based system does not anticipate a direct contact between officers and inmates and their families. The self-service system that is connected to SDP includes the requirement of coaching document proof. Therefore, it must be properly systemized through print attendance, which has an effect on register $\mathrm{F}$ and consequently ensures that there is no data manipulation.

- From the credibility dimension (truth, honesty, and supervision), inmates are forced to pay some levies, either in the form of money or goods, in exchange for their information technology-based rights.

\section{CONCLUSION}

The findings of this study show that service quality is influenced by the credibility and integrity correctional staff. The readiness of the facilities and infrastructure, such as adding features in SDP applications and allowing self-service as well as collecting inmate's data to facilitate the process of granting them their rights, can be evaluated directly by the inmates themselves, their families, and the interested communities.

In conclusion, it is clear that IT will help prisoners access their rights, especially the rights to remission, assimilation, family visit leaves, conditional exemption, free approach leaves, and conditional leaves. Therefore, the infrastructure of IT should be built in every correctional institution in Indonesia to ensure that inmates are able to access services offered through the SDP system.

\section{RECOMMENDATIONS}

Based on the results of this study, some recommendations on the accessibility of inmates' information technology-based rights include the following.

- Amendments to the Regulation of the Minister of Law and Human Rights Number 3 of 2018 concerning Terms and Procedures for Giving Remission, Assimilation, Family Visit Leave, Conditional Exemption, Free Approach Leave, and Conditional Leave, based on IT, key among them being the following:

- A willingness to work together with law enforcement officers to help dismantle cases of crimes committed, as evidenced by a statement submitted by law enforcement officers to correctional officers during the registration process that integrated the correctional data base;
- A Director General who supervises, controls, and evaluates the process of proposing, stipulating, implementing, and revoking remission, assimilation, leaves to visit family, parole, leaves before Free, and conditional leaves through correctional information systems that should be published and to which the general public are allowed access; and

- Approvals for the granting of the rights of prisoners to prisoners who are subject to criminal sanctions under one year or minor criminal offenses be carried out by heads of correctional institutions. There is no need to seek approvals from the Director General, as these approvals should only be monitored and supervised.

- There is a need for additional self-service computers so as to ensure that their numbers are proportional to the number of inmates and that the services offered through the SDP system are easily accessed by inmates and their families.

- It is necessary to evaluate the application of the SOP and SDP so as to ensure that they are in line with the correctional business process because they form an integral part of the organization and procedure of the Directorate General of Corrections.

- It is necessary to add a few features in the SDP application, such as features clearly showing the process of granting inmates their rights. In addition, the inmates, their families, and lawyers should be granted direct access to these features.

- It is important to improve and strengthen the value of integrity through a reward and punishment system so as eliminate the practice of illegal levies in granting inmates their rights.

- Methods of disseminating the information related to the ease of granting inmates their rights (remission, assimilation, leave to visit family (CMK), parole (PB), free approaching leave (CMB), and conditional leave (CB)) - to the inmates themselves, their families, and the general public-should be enhanced based on developments in IT.

\section{ACKNOWLEDGMENTS}

This research was made possible as a result of the synergy in the Ministry of Law and Human Rights. I wish to thank everyone who participated in this research, particularly the Head of the Research and Development Agency of Law and Human Rights and the Head of Law Research and Development Center of Research. Further, I would like to acknowledge the research team that carried out research on the accessibility of inmates through information technology. I would also like to thank The Division of Publication Facilitation of Law and Human Rights Research. 


\section{REFERENCES}

[1] Butarbutar, R 2016, Kompilasi hukum pidana dan aplikasinya di masyarakat, Gramata Publishing, Bekasi, Indonésie.

[2] Efendi, J 2018, Rekonstruksi dasar pertimbangan hukum hakim berbasis nilai-nilai hukum dan rasa keadilan yang hidup dalam masyarakat, Prenadamedia Group, Depok, Indonésie.

[3] Kepolisian Daerah Bali, dan Departemen Kriminologi Universitas Indonesia 2018, Laporan Tentang Gambaran Umum Kepuasan Masyarakat Bali Terhadap Kinerja Dan Kualitas Pelayanan Kepolisian Daerah Bali. Bali: Kepolisian Daerah Bali.

[4] Hoedi, P \& Sutopo, W 2018, 'Industri 4.0: Telaah klasifikasi aspek dan arah perkembangan riset', Jurnal Teknik Industri, vol. 13, no. 1.

[5] Magribi, LOM \& Suhardjo, A 2004, 'Aksesibilitas dan pengaruhnya terhadap pembangunan pedesaan: Konsep model sustainable accessibility pada kawasan pedesaan di propinsi Sulawesi Tenggara', Jurnal Transportasi, vol. 4, no. 2.

[6] Merkel, A 2014, 'Speech by Federal Chancellor Angela Merkel to the OECD Conference', viewed March 2017, https://www.bundesregierung.de/Content/EN/Rede n/2014/2014-02-19-oecd-merkel-paris_en.html.

[7] Ramseook-Munhurrun, P, Lukea-Bhiwajee, SD \& Naidoo, P 2010, 'Service quality in the public service', International Journal of Management and Marketing Research, vol. 3, no. 1, pp. 37-50.

[8] Rini RAP 2018, 'ORI Temukan Lapas Dan Rutan Tak Penuhi Hak Warga Binaan', TRIBUNNews, viewed February 22, 2019, http://www.tribunnews.com/nasional/2018/09/24/or i-temukan-lapas-dan-rutan-tak-penuhi-hak-wargabinaan.

[9] Staf Ahli Menteri Hukum dan Hak Asasi Manusia Republik Indonesia. Policy Brief Aksesibilitas Hak Warga Binaan (Remisi, Asimilasi, Cuti Mengunjungi Keluarga (CMK), Pembebasan Bersyarat (PB), Cuti Menjelang Bebas (CMB), Dan Cuti Bersyarat (CB)) Berbasis Teknologi Informasi. Jakarta, 2018.

[10] Widiarini, AD 2018, 'Milenial, Siap-siap Sambut Revolusi Industri 4.0', KOMPAS, viewed , https://edukasi.kompas.com/read/2018/10/03/17521 731/milenial-siap-siap-sambut-revolusi-industri-40.

[11] Widyonarso, ES \& Yuliastuti, N 2014, 'Tingkat aksesibilitas fasilitas sosial berdasarkan konsep unit lingkungan di perumnas banyumanik kota, semarang', Jurnal Ruang, vol. 2, no. 4, pp. 351360.

[12] Yanto, O, Rachmayanthy \& Satriana, D 2019, 'Implementation of remission for female prisoner as one of the rights in the correction system', Jurnal IUS, vol. 8, no. 1, pp. 2-13. 